\title{
THE EFFECT OF PERIWINKLE SHELL ASH MIXED WITH CEMENT ON WATER ABSORPTION AND SHRINKAGE OF LATERITIC BLOCK
}

\author{
Mfon Ekanem ANTIA ${ }^{1}$, Ikenna Reginald AJIERO², Paul Chuks ANIH ${ }^{3}$ \\ ${ }^{1,2,3}$ University of Uyo, Uyo, Akwa Ibom State, Nigeria \\ Corresponding author's e-mail: paulanih@uniuyo.edu.ng
}

\begin{abstract}
The aim of the study is to examine the effect of periwinkle shell ash (PSA) blended with cement on the water absorption and shrinkage of lateritic blocks. The objectives that would help achieve the stated aim are to investigate the water absorption and shrinkage properties of lateritic blocks blended with periwinkle shell ash/cement. The following methods were used during the research: sedimentation test, standard proctor test, Atterberg's limit test, smell and Nibble tests. Specific gravity of PSA, bulk density and porosity of PSA were carried out. $5 \%$ of the cement and percentage replacement levels of $0 \%, 10 \%$, $20 \%, 30 \%, 40 \%$ and $50 \%$ of cement with PSA were used for block production. $21 \mathrm{~cm} \times 10 \mathrm{~cm} \times 10 \mathrm{~cm}$ blocks were moulded, cured and subjected to water absorption and shrinkage tests. Data were collected and analysed using graphs, correlation and regression analyses. Result shows that percentage water absorption for replacement levels $0 \%, 10 \%, 20 \%, 30 \%$ were $12.08 \%, 16.38 \%$, $18.21 \%, 19.95 \%$. Again, from $0 \%$ replacement to $30 \%$ replacement of cement with PSA, the linear shrinkage increased from $1.5 \mathrm{~mm}$ to $2.8 \mathrm{~mm}$. It implies that up to $30 \%$, the maximum crack the block could form is $2.8 \mathrm{~mm}$, whereas the maximum allowable crack width for walling materials is $3.0 \mathrm{~mm}$. Therefore, percentage replacement of up to $30 \%$ is recommended for use in lateritic block.
\end{abstract}

Keywords: absorption, cement, lateritic block, Periwinkle Shell Ash (PSA), shrinkage, water.

\section{INTRODUCTION}

One of the major building materials used in Nigeria is cement. Lilly and Wai (2001) reported that in 1975 the demand for cement was 4950000 metric tons; in 1978 it was 7220000 metric tons; in 2000 the demand increased to about 16000000 metric tons. On the other hand, domestic production moved from 1200000 metric tons to 5000000 metric tons. The work revealed that Nigeria produced less than $30 \%$ of its demand. This excessive importation leads to an increase in the price of the product making the cost unbearable to the low-income earners and a reduction in the number of houses built.

In order to satisfy this inevitable request for reducing costs of building materials, there has been a drive towards sourcing for local, cheap and affordable materials that could replace the imported and costly ones, provided that the local materials could meet the desired engineering characteristics. Reports by Adesanya (1990), Moslemi and Lim (1984), Mutuli et al. (1982) show that fibre has been incorporated into concrete and other cement-based materials to improve their 
properties. Natural fibre has been substantially effective and economical, especially when used in low-rise building construction (ACOTEC, 1988). Lilly and Wai (2001) identified that the production of building materials using locally available raw materials was beset with limiting factors, such as capital intensiveness, lack of use of research, instability of the economy and lack of political will. Out of these factors, the one that arouses curiosity is the fact that research conducted is either dumped unused or little credence is given to the ideas of research in promoting technological and industrial revolution envisaged in Nigeria.

Government effort in bringing down the cost of materials was pursued through the Nigerian Building and Road Research Institute in the 1980s, which aimed at encouraging the utilisation of local materials for building production. Through this institute and other studies, several methods and local materials that can effectively be used for building production have been discovered. Some of these methods and materials are as follows: soil block stabilisation which may be in the form of physically compacting (known as mechanical stabilisation) or altering the soil composition to obtain the desired characteristic, chemical stabilisation that employs the use of additives such as lime, bitumen gypsum and pozzolanas. Since the desired breakthrough is yet to be achieved, research in this line must continue.

The present research envisages that combining periwinkle shell ash in cement will produce lateritic blocks with low water absorption and shrinkage properties but still comply with the stated standards. If this is achieved, then a new era of cheap affordable and durable accommodation for the Nigerian populace is underway.

\section{WATER ABSORPTION OF SOIL BLOCKS}

Most walling materials especially those that are clay-based have the tendency of absorbing water and swelling up. It has been shown by many researchers, for instance, Kamang (1998) reported that worm cast used as a stabilising agent produced soil blocks with poor resistance to water absorption. Nevertheless, the soil block produced with worm cast as a stabilising agent improved compressive strength, but poor resistance to water absorption made the worm cast soil block ineffective. Likewise, Adesanya (2000) showed that corncob incorporated in soil block tended to increase water absorption. He went on to state that water absorption increased with an increase in the amount of corncob used.

Islam et al. (2014) opined that the increase in cement content reduced the absorptive capacity of bricks. They revealed in their work that the absorptive capacity of brick stabilised with cement only was in order of $8.26 \%, 9.20 \%, 9.0 \%$ and $10 \%$ for $12 \%, 10 \%, 8 \%$ and $6 \%$ cement stabilisation, respectively. They went on to state that the rate of water absorption increased when Rice Husk Ash was incorporated and showed its linear proportionality.

Okoli (1998) also revealed that soils stabilised with lime clay having $9 \%$ lime, $40 \%$ clay and $51 \%$ laterite by weight exhibited the highest water resistance. Eko et al. (2006) opined that adding cement beyond a particular threshold made it less competitive. Researchers quoted this level to be $8 \%$, i.e., the amount of cement used should not exceed $8 \%$. A report by Meukam et al. (2002) revealed that at over $8 \%$ cement content, addition of cement yielded no effect on the absorption of water. 
Thermal conductivity increases with water content. When excessive heat is conducted into the building, it becomes uninhabitable; hence, for lateritic block to be effective, it must absorb minimum amount of water that will lessen the amount of heat introduced into the building. A report by Meukam et al. (2002) revealed that the use of sawdust in the production of lateritic block made the block to absorb water in the form of vapour. According to the researchers, it was due to the hygroscopic nature of sawdust.

\subsection{Shrinkage of Soil Blocks}

Laterite soil consists of particles such as gravel, sand, silt and clay. The clay component, which is the predominant particle, has the tendency to absorb water and swell up. During drying, clay shows a reasonable decrease in volume, conceptualised as shrinkage. It is in agreement with Houben and Guillaud (1995) who in their linear shrinkage test reported that when soil filled in a mould was allowed to dry, reduction in length was observed. This reduction in length is known as shrinkage. The alteration in volume is detrimental to the construction project as it weakens its component elements. Okpoko and Ali (2005) in their research revealed that compaction of soil block reduced porosity, increased density as well as compressive strength resistance to water absorption/shrinkage and abrasive wind.

\section{MATERIALS AND METHODS}

A total of 55 blocks were cast out of which 45 were used to test for compressive strength and 10 blocks were used to test for abrasive strength. The materials were batched by volume with various proportions of its components. The proportions were as follows: $5 \%$ cement; $0 \%, 10 \%, 20 \%, 30 \%, 40 \%$ and $50 \%$ periwinkle shell ash (PSA) to replace the cement. The soil was sieved using a 4.75 sieve size to obtain a homogenous soil. Cement was replaced by $0 \%, 10 \%, 20 \%, 30 \%, 40 \%$ and $50 \%$ of PSA by volume. In each case, $5 \%$ of the resulting binder by volume was thoroughly mixed with laterite. The optimum moisture content of $10 \%$ by weight of the laterite soil was added. Water was sprinkled on the mixture using watering can. The mixing was continued until a homogeneous mix was obtained. The resulting paste was compacted in a $210 \mathrm{~mm} \times 100 \mathrm{~mm} \times 100 \mathrm{~mm}$ mould.

\subsection{Results}

The suitability of the materials for lateritic block production as well as that of block for wall construction was determined through sedimentation test, standard proctor test, Atterberg's limits, smell and nibble test, as well as water absorption and shrinkage tests.

\subsection{Sedimentation Test}

The result of the sedimentation test of laterite soil is shown in Table 1. From the result analysis, the percentage composition of sand, silt and clay was 47.21 , 
34.95 and 17.84, respectively, which agrees with that recommended by the Nigerian Building and Road Research Institute (NBRRI) (1988).

Table 1. Sedimentation of Laterite Soil (developed by the authors, based on the conducted survey)

\begin{tabular}{ccc}
\hline Constituents of soil sample & Depth $(\mathbf{m m})$ & Percentage composition (\%) \\
\hline Sand & 292.7 & 47.21 \\
Silt & 216.7 & 34.95 \\
Clay & 110.6 & 17.84 \\
\hline Total & 620.0 & \\
\hline
\end{tabular}

Calculation of percentage composition (\%) is displayed in Eqs. (1)-(3).

$$
\begin{aligned}
& \text { Sand }=\frac{292.7 \cdot 100}{620}=47.21 \% \\
& \text { Silt }=\frac{216.7 \cdot 100}{620}=34.95 \% \\
& \text { Clay }=\frac{110.6 \cdot 100}{620}=17.84 \%
\end{aligned}
$$

Standard proctor test results are available further.

\subsection{Standard Proctor Test}

The laboratory compaction test of laterite soil carried out showed $10 \%$ water content by weight of laterite soil and gave a maximum dry density of $1.70 \mathrm{~kg} / \mathrm{m}^{3}$, which was considered the optimal water content. This water content falls within the 8-12\% range by weight of the laterite soil, recommended by British Standard BS 1377 (1975), for block making. The results further conform to 4-12\% by weight of laterite soil for block making inferred by Graham and Burt (2001). The result is presented in Table 2 and Fig. 1.

Table 2. Laboratory Compaction of Laterite (developed by the authors, based on the conducted survey)

\begin{tabular}{lcccccc}
\hline Water Content $(\%)$ & 4 & 6 & 8 & 10 & 12 & 14 \\
Mould + Soil sample, $M_{2}(\mathrm{~kg})$ & 6.40 & 6.50 & 6.55 & 6.60 & 6.51 & 6.45 \\
Weight of mould, $M_{1}(\mathrm{~kg})$ & 4.80 & 4.80 & 4.80 & 4.80 & 4.80 & 4.80 \\
Weight of sample, $M_{3}=M_{2}-M_{1}(\mathrm{~kg})$ & 1.60 & 1.70 & 1.75 & 1.87 & 1.71 & 1.65 \\
Volume of mould, $V\left(\mathrm{~m}^{3}\right)$ & 0.001 & 0.001 & 0.001 & 0.001 & 0.001 & 0.001 \\
Bulk density $P_{\mathrm{b}}=M_{3} / V\left(\mathrm{~kg} / \mathrm{m}^{3}\right)$ & 1600 & 1700 & 1750 & 1870 & 1710 & 1650 \\
Dry density $P_{\mathrm{d}}=P_{\mathrm{b}} /(1+w)$ & 1.54 & 1.61 & 1.62 & 1.70 & 1.49 & 1.59 \\
\hline
\end{tabular}




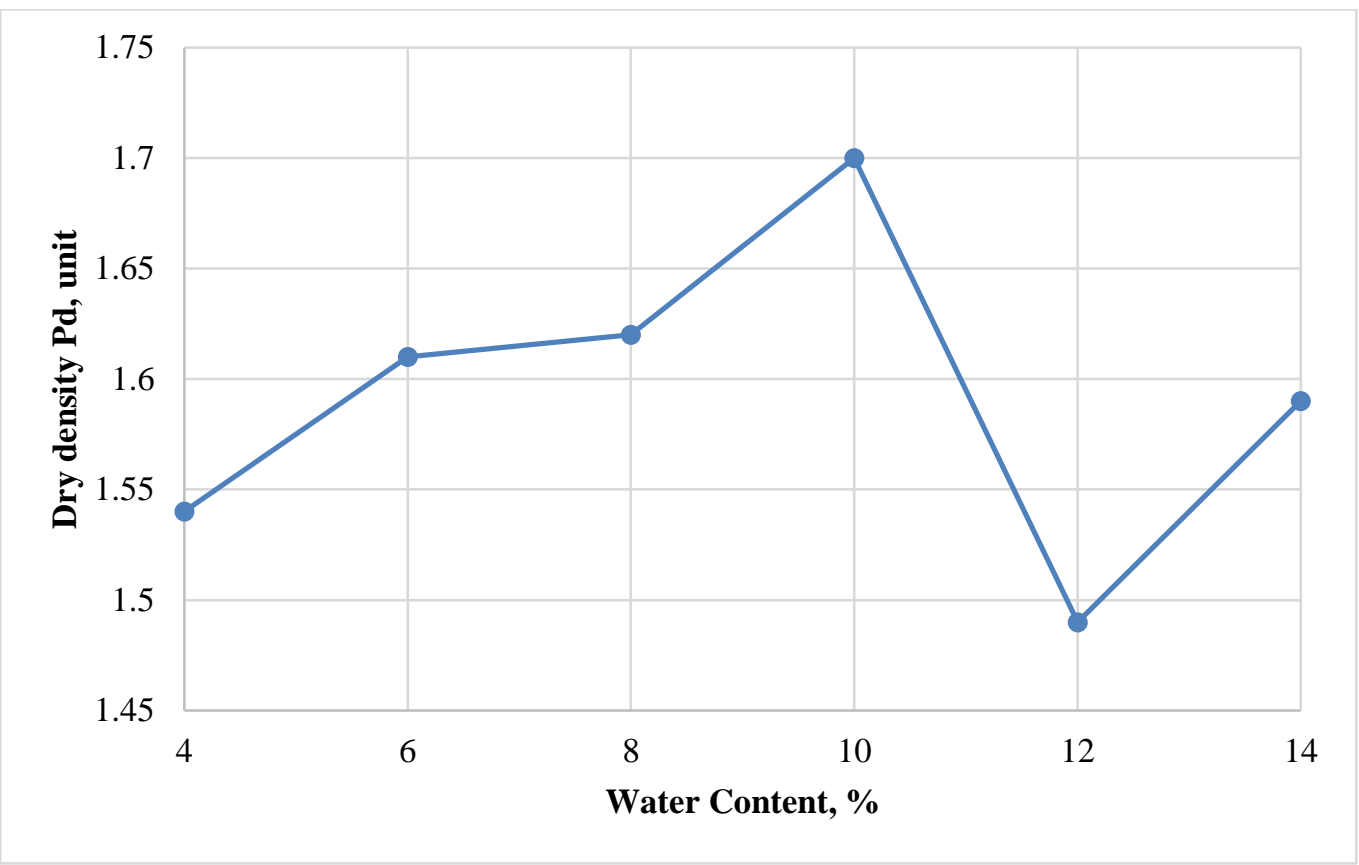

Fig. 1. Plot of dry density against water content (developed by the authors).

Information regarding Atterberg's limit is described further.

\subsection{Atterberg's Limit}

The result of the liquid limit of the lateritic soil is shown in Table 3 and Fig. 2 . The soil had a liquid limit value of $36 \%$. Table 4 presents the result of the plastic limit test. The value of the plastic limit of the laterite soil was $23.1 \%$. This gives a plasticity index of $13.4 \%$. This value falls within the range of $12-15 \%$ of laterite soil for block making (Graham \& Burt, 2000) and is also consistent with the specification of British Standard BS 1377 (1975). It reveals the cohesiveness of the laterite soil and its ability to receive adequate compaction in order to boost its strength.

Table 3. Liquid Limit of Laterite Soil (developed by the authors, based on the conducted survey)

\begin{tabular}{lcccc}
\hline Sample Number & 1 & 2 & 3 & 4 \\
\hline Number of blows & 15 & 18 & 27 & 32 \\
Weight of container, $M_{1}(\mathrm{~g})$ & 50 & 50 & 50 & 50 \\
Weight of container + wet soil, $M_{2}(\mathrm{~g})$ & 65.1 & 68.6 & 73.8 & 72.4 \\
Weight of dry soil + container, $M_{3}(\mathrm{~g})$ & 58.9 & 61.3 & 65.2 & 65.0 \\
Weight of water, $M_{4}=M_{2}-M_{3}(\mathrm{~g})$ & 6.2 & 7.3 & 8.6 & 7.4 \\
Weight of oven dried soil, $M_{5}=M_{3}-M_{1}$ & 15.1 & 18.6 & 23.8 & 22.4 \\
Water content $=\left(M_{4} \cdot 100\right) / M_{5}$ & 41.1 & 39.2 & 36.1 & 33.0 \\
\hline Liquid Limit from graph, $L L$ & & & $36 \%$ & \\
\hline
\end{tabular}


Table 4. Plastic Limit of Laterite Soil (developed by the authors, based on the conducted survey)

\begin{tabular}{lcc}
\hline Sample Number & 1 & 2 \\
\hline Weight of container, $M_{1}(\mathrm{~g})$ & 50 & 50 \\
Weight of soil + container, $M_{2}(\mathrm{~g})$ & 71.20 & 63.76 \\
Weight of dry soil + container, $M_{3}(\mathrm{~g})$ & 67.10 & 61.16 \\
Weight of water, $M_{4}=M_{2}-M_{3}$ & 4.10 & 6.16 \\
Oven dried soil $M_{5}=M_{3}-M_{1}$ & 17.90 & 11.16 \\
Water content $=\left(M_{4} \cdot 100\right) / M_{5}$ & 22.90 & 23.30 \\
\hline Plastic Limit, $P L$ & \multicolumn{2}{c}{$23.1 \%$} \\
\hline
\end{tabular}

Plasticity index is calculated in Eq. (4).

$$
\text { Plasticity Index }=L L-P L=36-23.1=13.4 \%
$$

Information regarding smell and nibble tests are provided further.

\subsection{Smell and Nibble Tests}

The sample was dug and immediately smelt. The sample did not have a musty smell. This implies not having an unpleasant odour indicative of the presence of organic matter. When heated it produced a pleasant smell. A sample of the soil was crushed lightly with the teeth and it ground with a disagreeable sensation. It shows that the soil was sandy.

\subsection{Periwinkle Shell Ash}

\subsubsection{Specific Gravity of Periwinkle Shell Ash}

The result of specific gravity of periwinkle shell ash is presented in Table 5 .

Table 5. Specific Gravity of Periwinkle Shell Ash (developed by the authors, based on the conducted survey)

\begin{tabular}{lccc}
\hline Sample Number & 1 & 2 & 3 \\
\hline Weight of density bottle, $M_{1}(\mathrm{~g})$ & 245.0 & 245.0 & 245.0 \\
Weight of bottle + dry sample, $M_{2}(\mathrm{~g})$ & 421.0 & 419.0 & 422.0 \\
Weight of bottle + sample + water, $M_{3}(\mathrm{~g})$ & 853.6 & 862.9 & 860.1 \\
Weight of bottle full of water, $M_{4}(\mathrm{~g})$ & 745.0 & 745.0 & 745.0 \\
Specific gravity $G \mathrm{~s}=\left(M_{2}-M_{3}\right) /\left[\left(M_{4}-M_{1}\right)-\left(M_{3}-M_{2}\right)\right]$ & 2.61 & 3.10 & 2.86 \\
\hline Mean Specific gravity & \multicolumn{3}{c}{2.86} \\
\hline
\end{tabular}


The result indicates a specific gravity of 2.86. This value is higher than 2.13 obtained for Rice Husk Ash (Abdullahi, 2005) but less than 3.15 for cement (British Standard BS 1377, 1975) and higher than 2.04 for earthworm east (Kamang, 1998).

Information regarding bulk density and porosity of periwinkle shell ash is provided in the next sub-section.

\subsubsection{Bulk Density and Porosity of Periwinkle Shell Ash}

The bulk density of periwinkle shell ash is presented in Table 6 . The value for mean uncompacted bulk density is $2369.46 \mathrm{~kg} / \mathrm{m}^{3}$ and that for compacted bulk density is $3113.0 \mathrm{~kg} / \mathrm{m}^{3}$ as shown in Table 7 . The porosity of the periwinkle shell ash was $23.8 \%$. Thus, there is a clear indication of low internal pores in the ash, with a buffering effect on the compressive strength.

Table 6. Uncompacted Bulk Density (developed by the authors, based on the conducted survey)

\begin{tabular}{lccc}
\hline Sample Number & 1 & 2 & 3 \\
\hline Weight of mould, $M_{1}(\mathrm{~kg})$ & 0.059 & 0.059 & 0.059 \\
Weight of mould + Sample, $M_{2}(\mathrm{~kg})$ & 0.455 & 0.500 & 0.430 \\
Weight of sample, $M_{3}=M_{2}-M_{1}(\mathrm{~kg})$ & 0.396 & 0.441 & 0.371 \\
Volume of mould, $V\left(\mathrm{~m}^{3}\right)$ & 0.17 & 0.17 & 0.17 \\
Uncompacted Bulk Density $=M_{3} / V\left(\mathrm{~kg} / \mathrm{m}^{3}\right)$ & 2329.4 & 2594.1 & 2184.9 \\
\hline Mean Uncompacted Bulk Density $\left(\mathrm{kg} / \mathrm{m}^{3}\right)$ & & 2369.46 & \\
\hline
\end{tabular}

Table 7. Compacted Bulk Density (developed by the authors, based on the conducted survey)

\begin{tabular}{lccc}
\hline Sample Number & 1 & 2 & 3 \\
\hline Weight of mould, $M_{1}(\mathrm{~kg})$ & 0.059 & 0.059 & 0.059 \\
Weight of mould + Sample, $M_{2}(\mathrm{~kg})$ & 0.569 & 0.591 & 0.605 \\
Weight of sample, $M_{3}=M_{2}-M_{1}(\mathrm{~kg})$ & 0.510 & 0.532 & 0.564 \\
Volume of mould, $V\left(\mathrm{~m}^{3}\right)$ & 0.17 & 0.17 & 0.17 \\
Compacted Bulk Density $=M_{3} / V\left(\mathrm{~kg} / \mathrm{m}^{3}\right)$ & 3000.1 & 3128.7 & 3210.2 \\
\hline Mean Compacted Bulk Density $\left(\mathrm{kg} / \mathrm{m}^{3}\right)$ & & 3113.0 & \\
\hline
\end{tabular}

Information regarding porosity of periwinkle shell ash is provided further.

\subsubsection{Porosity of Periwinkle Shell Ash}

Eq. 5 and related calculations represent the porosity of periwinkle shell ash. 
Porosity $=($ mean weight of compacted PSA - mean weight of uncompacted PSA . 100)/3; Mean weight of compacted PSA $=(0.510+0.532+0.546) / 3=0.529$; Mean weight of uncompacted PSA $=(0396+0.441+0.371) / 3=0.403$.

$$
\text { Porosity PSA }=\frac{(0.529-0.403) \cdot 100}{3}=28.3 \%
$$

Information regarding the water absorption is provided in the next sub-section.

\subsection{Water Absorption}

The result of the test (Table 8 ) reveals that from $0 \%$ to $30 \%$ replacement, the percentage water absorption was within the limit specified for soil block but beyond $30 \%$ replacement the value was above $20 \%$ maximum specified by CDI and Terre (1995). It was in line with Mors and Jonkers (2017) who opined that the increase in cement reduced water absorption. The regression plot (Fig. 2) gives a regression coefficient of 0.983 showing that there is a linear relationship between the percentage replacements of cement with PSA. $R^{2}$ value of 0.983 implies that $98.3 \%$ water absorption can be accounted for by the linear relationship.

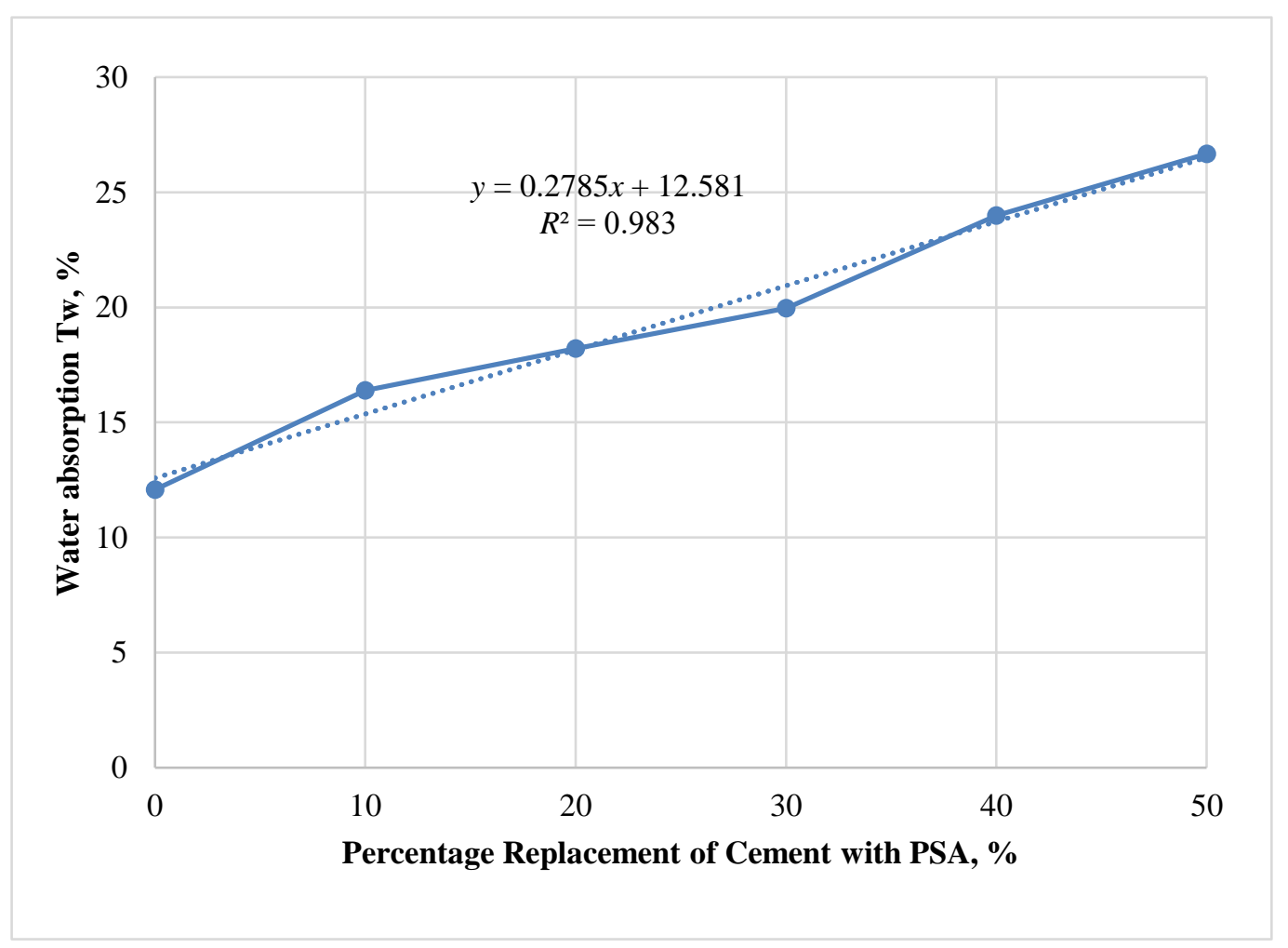

Fig. 2. Regression plot of water absorption on the $28^{\text {th }}$ day. 
Table 8. Water Absorption of Lateritic Block (developed by the authors, based on the conducted survey)

\begin{tabular}{cccc}
\hline \multirow{2}{*}{$\begin{array}{c}\text { Replacement of cement } \\
\text { with PSA }(\%)\end{array}$} & \multicolumn{2}{c}{ Weight of Block } & Water Absorption, \\
\cline { 2 - 2 } & $\begin{array}{c}\text { Dry Weight, } M_{\mathrm{S}} \\
(\mathrm{kg})\end{array}$ & $\begin{array}{c}\text { Wet Weight, } M_{\mathrm{H}} \\
\text { TW }(\%)\end{array}$ \\
0 & 3.56 & 3.99 & \\
10 & 3.54 & 4.12 & 12.08 \\
20 & 3.57 & 4.22 & 16.38 \\
30 & 3.66 & 4.39 & 18.21 \\
40 & 3.67 & 4.55 & 19.95 \\
50 & 3.64 & 4.60 & 23.98 \\
\hline
\end{tabular}

Information regarding shrinkage is provided further.

\subsection{Shrinkage}

The result of the test (Table 9) shows that an increase in the percentage replacement of cement with PSA gives a corresponding increase in shrinkage. From $0 \%$ replacement to $30 \%$ replacement of cement with PSA, the linear shrinkage increased from $1.5 \mathrm{~mm}$ to $2.8 \mathrm{~mm}$. It shows that at $30 \%$, the block may form a crack of $2.8 \mathrm{~mm}$. Beyond $30 \%$, the linear shrinkage was $3.4 \mathrm{~mm}$ at $40 \%$ and 3.8 at $50 \%$, likely to form a crack of $3.4 \mathrm{~mm}$ and 3.8 , respectively. The maximum allowable width for walling materials is $3.0 \mathrm{~mm}$ (Indian Standard Institution IS 8112: 1989). It implies that up to $30 \%$ replacement of cement with PSA, the linear shrinkage is within an acceptable range, beyond which the likely crack becomes too large.

The regression plot (Fig. 2) gives a regression coefficient $R^{2}$ value of 0.9697 indicating that $96.97 \%$ of shrinkage can be accounted for by the linear relationship. Eq. 6 is provided further. Fig. 3 represents the regression plot of shrinkage on the $28^{\text {th }}$ day.

$$
\begin{gathered}
Y=0.1072 x+3.2557 \\
R^{2}=0.9697
\end{gathered}
$$

Table 9. Shrinkage of Lateritic Block (developed by the authors, based on the conducted survey)

\begin{tabular}{ccccc}
\hline $\begin{array}{c}\text { Replacement of Cement } \\
\text { with PSA (\%) }\end{array}$ & $\begin{array}{c}\text { Wet Length } \\
L_{\mathrm{w}}(\mathrm{mm})\end{array}$ & $\begin{array}{c}\text { Dry Length } \\
L_{\mathrm{d}}(\mathrm{mm})\end{array}$ & $\begin{array}{c}\text { Shrinkage } \\
L_{\mathrm{w}}-L_{\mathrm{d}}(\mathrm{mm})\end{array}$ & $\begin{array}{c}\text { Percentage } \\
\text { Shrinkage (\%) }\end{array}$ \\
\hline 0 & 41.75 & 40.25 & 1.5 & 3.59 \\
10 & 41.90 & 40.10 & 1.8 & 4.30 \\
20 & 42.20 & 40.20 & 2.0 & 4.74 \\
30 & 42.80 & 40.00 & 2.8 & 6.54 \\
40 & 43.46 & 40.06 & 3.4 & 7.82 \\
50 & 44.10 & 40.50 & 3.8 & 8.62 \\
\hline
\end{tabular}




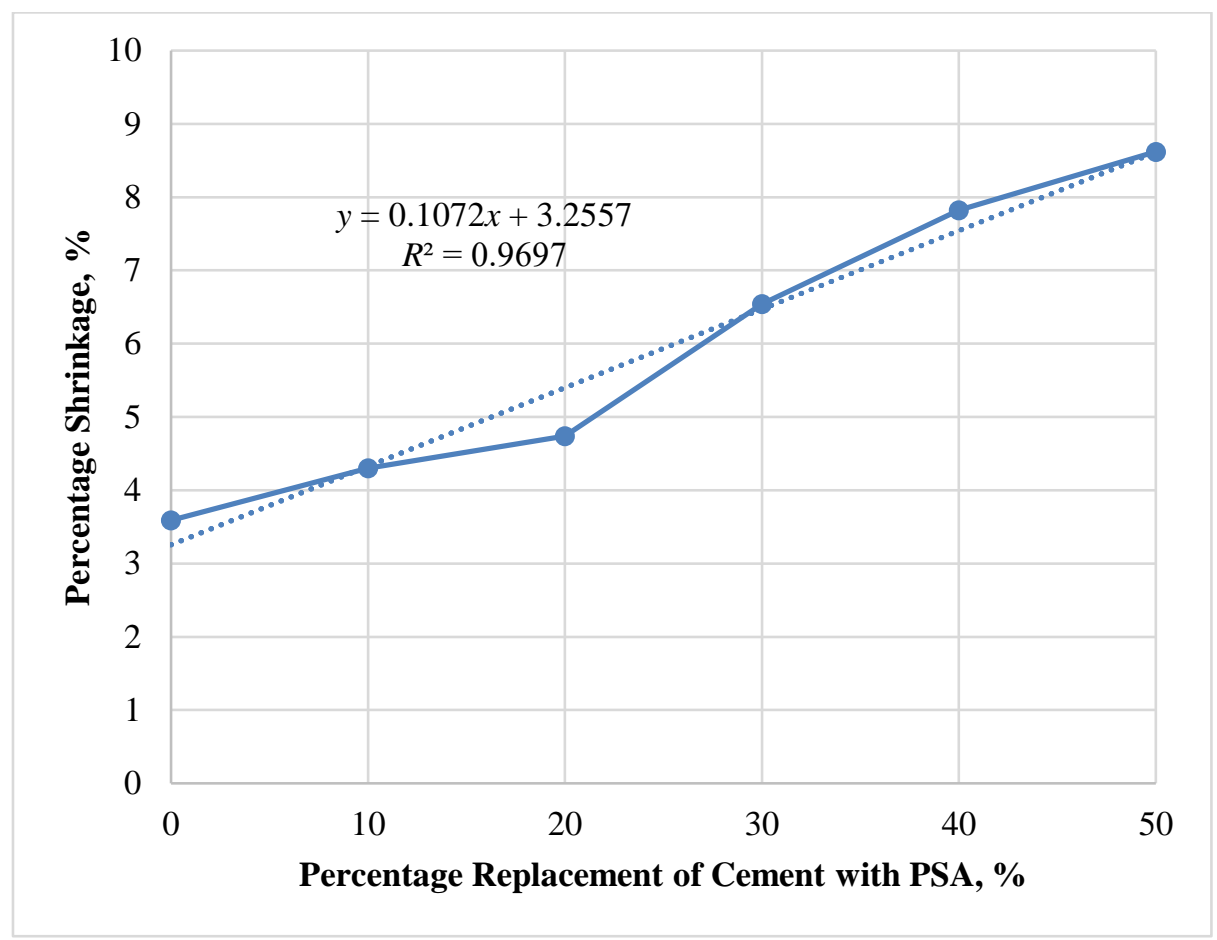

Fig. 3. Regression plot of shrinkage on the $28^{\text {th }}$ day (developed by the authors).

The summary of findings is provided further.

\subsection{Summary of Findings}

The findings of the research are summarised as follows. The particle distribution of the soil used for the research was $46 \%$ sand, $41 \%$ silt and $13 \%$ clay, which was in line with the recommendation of 35-50\% sand, 40-50\% silt and 10-20 \% clay (Nigerian Building and Road Research Institute, NBRRI, 1988). It was also observed that the optimum water content for the soil used was $10 \%$, which complied with the 8-12\% water content for block making (British Standard Institution, BS 1377, 1995) and 4-12\% by weight of laterite (Graham \& Burt, 2001). The plasticity index of the soil was $3.4 \%$, which was within the limits of 12-15\% for block making (British Standard Institution, BS 1377, 1995). The smell test indicated the absence of organic matter, while the nibble test showed that sand content of the soil was high. These characteristics give good quality soil for block making (Abdullahi, 2001). The specific gravity of the periwinkle shell ash was 2.86 and its bulk density was $3113.0 \mathrm{~kg} / \mathrm{m}^{3}$ with porosity of $23.8 \%$.

The result of water absorption revealed that in the lateritic block up to $30 \%$ replacement was within 10-20\% limits recommended by CD1 and Terre (1995). The percentage water absorption was $12.08 \%, 16.38 \%, 18.21 \%, 19.95 \%$, $23.98 \%$ and $26.67 \%$ for $10 \%, 20 \%, 30 \%, 40 \%$ and $50 \%$ replacement of cement with PSA, respectively.

The research also showed that the blocks had low shrinkage values. At50\% replacement, a value of $3.8 \mathrm{~mm}$ giving percentage shrinkage of $8.62 \%$ was obtained as the highest shrinkage. This is in line with Abdullahi (2001) who 
maintained that soils with more than $30 \%$ clay often have very high ratios of shrinkage and swelling. This often results in cracks in the final product, mainly due to moisture absorption.

\section{CONCLUSION}

Within the limits of the study and findings, the following deductions were made:

A. Up to $30 \%$ replacement, the blocks had percentage water absorptions that were within 10-20\% limits (CDI and Terre, 1995). Beyond this value, the percentage water absorption exceeded the limits;

B. The shrinkage of the block was generally low as the laterite used contained less clay;

C. The percentage replacement of cement with PSA affected the shrinkage as well as water absorption of the lateritic block.

\section{Recommendations}

The shrinkage values $(4.30 \%, 4.74 \%$ and $6.54 \%)$ were low and, therefore, suitable for block production.

Percentage water absorptions $(16.38 \%, 18.21 \%$ and $19.95 \%)$ were within 10-20\% limit for water absorption (CD1 and Terre, 1995) and, therefore, recommended for block production.

However, during the course of the research, a gradual increase in shrinkage and water absorptions were observed and may be adduced to the fact that reducing the amount of cement and increasing the PSA gave an excess amount of the ash required to combine with calcium hydroxide in the cement.

\section{REFERENCES}

Abdullahi, M. (2005). Effect of Water Cement Ratio on the Compressive Strength and Workability of Concrete and Laterite concrete mixes. International Journal for Computational Civil and Structural Engineering, 2(3).

Abdullahi, M. (2001). Characteristics of Wood Ash/OPC Concrete. Civil Engineering Department, Federal University of Technology, Minna, Niger State, Nigeria.

Adesanya, D. (1990). The Behaviour of Corn Husk Fibre Reinforced earth block. Journal of Tropical Architecture, 4(3), 16-26.

Adesanya, D. (2000). The characteristics of laterite bricks and blocks stabilized with corncob fillers. The professional Builder, Journal of the Nigerian Institute of Building, pp 47-55.

Advanced Construction Technology - ACOTEC. (1988). FIBRICON - Fibre concrete Technology. Finland.

British Standard Institution BS 1377. (1975), Soil Classification London.

CDI and Terre. (1995). Compressed Earth Blocks Standards. ISBN 2-906901-18-0.

Eko, R., Mpele, M., Dtawagap, D., Minsili, S., \& Wouatong, A. (2006). Some hydraulic, mechanical, and physical characteristics of three types of compressed earth blocks. Engineering International, the CIGR Journal. Vol. VIII.

Graham, W., \& Burt, R. (2001). BTEC Sustainable Building III, Conference Santa Fe, New Mexico, 17-18 October. 
Houben, H., \& Guillaud, H. (1995). Earth Construction a Comprehensive Guide. CRATeere- EAG. Intermediary Technology Publication, London.

Indian Standard Institution IS 8112. (1989). Materials Testing.

Islam, S., Hashim, R., Islam, A., \& Kurnia, R. (2014). Effect of Peat on Physicomechanical Properties of Cemented Brick. The Scientific World Journal, 2014. https://doi.org/10.1155/2014/328516

Kamang, E. (1998). Strength and Properties of Compressed Earth Blocks (CEB) with Earthworm Cast as Stabilizer. Journal of Environmental Science, 1(2), 65-70.

Lilly, M., \& Wai, J. (2001). The Professional Builder. J. of the Nigerian Institute of Build. pp. 48.

Meukam, P., Noumowe, A., \& Kofane, T. (2002). Thermophysical Properties of Lateritic Soil Bricks: Influence of water content. United Nations Educational Scientific and Cultural Organization and International Atomic Energy Agency. Retrieved from http://www.ictp.trieste.it/ pub_off

Mors, R., \& Jonkers, H. (2017). Effect on Concrete Surface Water Absorption upon Addition of Lactate Derived Agent. Coatings, 7(4), 51. https://doi.org/10.3390/coatings7040051

Moslemi, A., \& Lim, Y. (1984). Compatibility of southern hardwoods with portland cement. Forest Prod. J., 34(7/8), 22-26.

Mutuli, S. Besli, T., \& Talitwala, E. (1982). The potentials of sisal as reinforcing Fibre in Cement Base Materials. African Journal of Science and Technology, 1(1), 5-16.

Nigerian Building and Road Research Institute (NBRRI). (1988). Ten years of building and road research: 10th year anniversary commemorative publication. Edited by G.N. Omange. Nigerian Building \& Road Research Institute, 1988, 263. p.

Okoli, O. (1998). Unconfined Compressive Strength and durability of Lime - Clay Soil for Building Construction. Nigerian Journal of Construction Technology and Management, 1(1), 1-5.

Okpoko, A., \& Ali, J. (2005). Need for Quality in the Production of Cement Stabilized Soil Blocks for Walling in Nigeria. The Prof. Building J. of the Nigerian Institute of Building, pp. $64-72$.

\section{AUTHORS' SHORT BIOGRAPHIES}

Mfon Ekanem Antia works at the Department of Building, University of Uyo, Nigeria. He has a BSc. degree in Building (University of Uyo), MSc. degree in Building Maintenance (Obafemi Awolowo University), $\mathrm{PhD}$ (in-view) in Building Maintenance (Obafemi Awolowo University). He is a Member of the Nigerian Institute of Building. Specialization: Building Maintenance.

E-mail: mfonantia@uniuyo.edu.com

Ikenna Reginald Ajiero works at the Department of Building, University of Uyo, Nigeria. The author holds a BSc. degree in Building (University of Uyo), MSc. degree in Building Service Engineering (Glasgow Caledonian University), $\mathrm{PhD}$ in Construction (Herriot Watt University). Ikenna Reginald Ajiero is a Corporate Member of the Nigerian Institute of Building and registered by the Council of Registered Builders of Nigeria (CORBON). Specialization: Building Services.

E-mail: reginaldikenna@uniuyo.edu.com

Paul Chuks Anih is a Lecturer at the Department of Estate Management of the University of Uyo, Nigeria. He studied estate management at the University of Nigeria, Nsukka. He received the PhD degree in Estate Management from the University. He specialises in facility/property management and property development and finance. Dr. Anih is currently a Senior Lecturer at the University of Uyo, Nigeria. He is the incumbent Head of Department, Estate Management. He has articles in both international and local journals. He has also presented papers in both local and international (Nairobi) conferences. He is an Associate Member of the Nigerian Institution of Estate Surveyors and Valuers (NIESV) and a registered member of Estate Surveyors and Valuers Registration Board of Nigeria (ESVARBON). The author has two awards to his credit: The Award of Excellence for examination officer and The Award of Recognition for paper presentation at NIESV National Conference, 2019.

E-mail: paulanih@uniuyo.edu.ng ORCID iD: https://orcid.org/0000-0003-2636-9511 